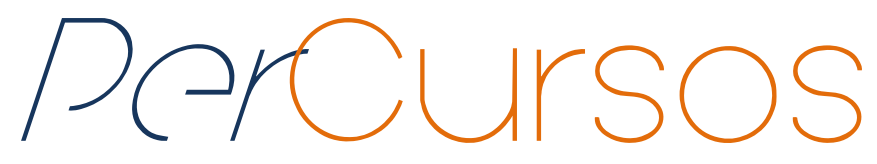

\title{
A cidade como filme: cinema e cultura moderna na Curitiba da Primeira República
}

\section{Resumo}

Como outras cidades brasileiras do período, Curitiba, capital do Paraná, vive nos primeiros anos do século $X X$ um significativo processo de transformações, que afeta suas esferas material e sociocultural. Uma gramática é construída para nominar esse novo universo: lazer, prazer, aventura, hedonismo; mas também individualismo, estranhamento, indiferença, multidão, insegurança, risco. A intenção deste artigo é apontar as diferentes maneiras de ler a modernização e a modernidade e suas diferentes percepções a partir da relação dos curitibanos do período com o cinema por meio da imprensa. Eleito um dos signos de uma nascente cultura urbana moderna, o cinematógrafo exerceu um misto de fascínio, curiosidade e temor, servindo como uma alegoria possível para se discutir alguns aspectos do processo de formação da modernidade curitibana e das novas e contraditórias sensibilidades que emergem a partir dela.

\section{Clóvis Gruner}

Doutor em História pela Universidade Federal do Paraná UFPR. Professor da Universidade Federal do Paraná - UFPR. Brasil clovisgruner@gmail.com

Palavras-chave: Imprensa; Cidade; Modernidade; Cultura urbana.

\section{Para citar este artigo:}

GRUNER, Clóvis. A cidade como filme: cinema e cultura moderna na Curitiba da Primeira República. Revista PerCursos, Florianópolis, v. 17, n.33, p. 56 - 81, jan./abr. 2016.

\section{DOI: $\mathbf{1 0 . 5 9 6 5 / 1 9 8 4 7 2 4 6 1 7 3 3 2 0 1 6 0 5 6}$}

http://dx.doi.org/10.5965/1984724617332016056 


\title{
The city as film: cinema and modern culture in Curitiba of the First Republic
}

\begin{abstract}
Like other Brazilian cities of the period, Curitiba, capital of Paraná, lives, in the early years of the twentieth century, a significant transformation process that affects their material and socio-cultural fields. A grammar is built to name this new universe: leisure, pleasure, adventure, hedonism; but also individualism, estrangement, indifference, crowd, insecurity, risk. The aim of this article is to point out the different ways to read the modernization and modernity in its different perceptions of the relationship of the curitibanos with the cinema throught the press. Chosen one of the signs of a nascent modern urban culture, the cinematograph played a mixture of fascination, curiosity and fear, serving as a possible allegory to discuss some aspects of the training process of Curitiba modernity and of new and contradictory sensibilities that emerge from it.
\end{abstract}

Keywords: Press; City; Modernity; Urban culture. 
Ontem à noite, eu estava no Reino das Sombras.

Máximo Gorki

O sonho da multidão começa. Jules Romain (Puissances de Paris)

No texto dedicado à reprodutibilidade técnica da obra de arte, Walter Benjamin apontava algumas das características que tornavam o cinema a única forma de arte nascida no interior da modernidade e, ao mesmo tempo, a linguagem por excelência capaz de tecer a narrativa desta mesma modernidade. De acordo com o teórico alemão, o cinema se integra a ela em seu afã pela técnica, do qual não pode prescindir, e pelo movimento contínuo: o ritmo vertiginoso com que são exibidos os fotogramas cria a ilusão de mobilidade, inventa uma nova imagem a cada quadro, obrigando o espectador a uma atenção ao mesmo tempo aguda, constante e dispersa. Não há possibilidade de contemplação, mas o choque e a vertigem provocados pela (ou sensação de) velocidade: "Ela [a imagem] não pode ser fixada, nem como um quadro nem como algo de real. A associação de ideias do espectador é interrompida imediatamente, com a mudança da imagem". Daí porque, ainda segundo Benjamin, o "cinema é a forma de arte correspondente aos perigos existenciais mais intensos com os quais se confronta o homem contemporâneo" (BENJAMIN, 1993, p. 192). ${ }^{1}$ Na esteira de outras invenções tecnológicas que corroboram para acelerar o tempo e encurtar distâncias, ou os dois tais como o trem, o automóvel e, um pouco mais tarde, o avião - ele exacerba a relação entre o moderno e o transitório. E é bastante significativo, afinal, que a primeira imagem exibida publicamente por um cinematógrafo, tenha sido, justamente, a de um trem em movimento chegando à estação.

Símbolo e signo da modernidade, portanto, o cinema é também pretexto: o impacto que as exibições do cinematógrafo tiveram na cultura urbana do final do século XIX e inícios do XX, o misto de fascínio e temor que ele provocou, servem como alegorias para discutir alguns aspectos do processo de formação da própria modernidade,

\footnotetext{
${ }^{1}$ A vinculação entre modernidade e transitoriedade não é nova: ainda no século XIX, Baudelaire a reivindicava como um dos domínios do artista moderno, que tinha entre seus prazeres "escolher domicílio no número, no ondulante, no movimento, no fugidio e no infinito" (BAUDELAIRE, 2006, p. 287).
} 
entendida aqui, a partir de Singer, em seus sentidos moral e político (a traduzir o “desamparo ideológico” de um mundo pós-sagrado e pós-feudal); cognitivo (que aponta para o surgimento de uma racionalidade instrumental como nova moldura intelectual); socioeconômico (ao designar as mudanças tecnológicas e sociais, de caráter mais “objetivo", tais como a industrialização e a urbanização); e neurológico. Ainda que essas quatro concepções sejam relacionais e complementares, é sobre esta última especialmente que gostaria de me debruçar com um pouco mais de atenção. Para Singer, a "modernidade também tem que ser entendida como um registro da experiência subjetiva fundamentalmente distinto, caracterizado pelos choques físicos e perceptivos do ambiente urbano moderno". A concepção neurológica enfatiza, de acordo com este entendimento, a importância de pensar os modos pelos quais aquelas muitas mudanças apontadas acima - morais, políticas, cognitivas, econômicas, tecnológicas, etc... - foram apreendidas, lidas, interpretadas; enfim, “transformaram a estrutura da experiência”, mergulhando os indivíduos em um fluxo constante de estímulos sensoriais, um "bombardeio de impressões, choques e sobressaltos": tráfego de veículos, movimento intenso de transeuntes, abundância de informações e estímulos principalmente visuais, o contato, mesmo que transitório, com indivíduos e grupos estranhos e desconhecidos (SINGER, 2004, p. 95-96). Por paradoxal que pareça, é deste mundo onde a experiência resulta empobrecida pelo caráter exaurível dos acontecimentos, que o cinema oferece uma fuga reproduzindo, na tela branca, justamente aquilo de que o público pretendeu evadir-se: a realidade como espetáculo ininterrupto, a vida como um filme.

Nascido sob a égide da modernidade, portanto, o cinema desdobra e aprofunda um novo "regime de percepção" que surge e se consolida ao longo do século XIX e que tem na reprodução técnica e na crescente espetacularização da realidade dois de seus principais suportes. A penetração da técnica em uma nascente "sociedade do espetáculo", a constituição de uma "cultura visual" como parte de um mundo fragmentado e disperso, altera não apenas as formas de produção de imagens, mas modifica igualmente o lugar do observador, aquele que vê, e o estatuto do objeto observado, que se desloca principalmente para o corpo e seus muitos sinais (CRARY, 1992, p. 97-136). Para Jonathan Crary, essas mudanças afetam principalmente a atenção 
que, submetida a constantes estímulos e distrações, torna-se ainda mais necessária, vital. “A centralidade deste problema [da atenção] estava diretamente ligada ao surgimento de um campo social, urbano, psíquico e industrial cada vez mais saturado de informações sensoriais. A desatenção (...) passou a ser vista como um perigo e um problema sério (...)" (CRARY, 2013, p. 36).

Ao mesmo tempo, e contraditoriamente, são estas mesmas condições que impelem a uma percepção fragmentada e dispersa das coisas, pois parte da lógica do capitalismo exige aceitarmos como natural a mudança rápida da nossa atenção. Razão pela qual, segundo ainda Crary, a emergência de uma sociedade a um só tempo espetacular e tecnológica não afeta apenas o sentido da visão; ela "gerou uma constante recriação das condições de experiência sensorial, o que se poderia chamar de uma revolução dos meios de percepção". Em outras palavras, o que caracteriza a experiência da modernidade não é apenas a instituição de uma nova "visualidade", mas de novas formas de percepção, "um modo de aludir a um sujeito que se define em termos que vão além da modalidade do sentido único da visão, mas que incluem também a audição e o tato e, o que é mais importante, formas sensoriais irredutivelmente heterogêneas". O processo de "modernização da subjetividade", portanto, deve ser apreendido em uma dinâmica que, sem abdicar da importância das imagens fotográficas e cinematográficas e sua potencial capacidade de redimensionar o olhar e os modos de ver, a instituição de um novo "regime de visualidade", precisa ser posta "lado a lado com o surgimento de novas formas tecnológicas de espetáculo, exposição, projeção, atração e registro" (CRARY, 2013, p. 26). Um novo "regime de percepção", que abarca a visualidade, sem por isso tomá-la como objeto único na formação dessas novas formas de constituição e expressão das sensibilidades modernas.

O aparecimento do cinema, portanto, é parte de um conjunto mais amplo e complexo de acontecimentos que configuram essas "novas formas tecnológicas de espetáculo, exposição, projeção, atração e registro". A noção de espetáculo, principalmente, sofre ao longo da segunda metade do oitocentos um incremento sem precedentes, notadamente nas grandes cidades europeias. Há de um lado a expansão do mercado editorial e publicitário a constituir uma "comunidade de leitores" disposta a 
mediar sua relação com o mundo por meio da leitura cotidiana de revistas ilustradas, jornais, folhetins, crônicas e ficção policial, entre outras narrativas. Mas lado a lado com o crescimento deste mercado, há igualmente a instituição de uma "cultura de massa" vinculada, por exemplo, à profusão da publicidade e do consumo, mas igualmente estimulada pelo aparato tecnológico que abre novas e intrigantes possibilidades de experiência sensorial, tais como as viagens de trem, os passeios de automóvel, as exposições universais, os parques de diversões, museus de cera e panoramas. O cinema aparece na esteira desses eventos e se consolida incorporando muitos dos elementos já presentes em diversos aspectos da vida moderna. Ele surge, enfim, como parte de uma cultura visual mais ampla, e encontra um público já relativamente familiarizado com a novidade em virtude das experiências precedentes com aparatos tecnológicos os mais diversos (SCHWARTZ, 1998, p. 177-199). A audiência que em número cada vez maior acorre às exibições dos cinematógrafos leva para estes novos espaços modos de ver cultivados de atividades e práticas culturais que a antecederam e, sob diferentes aspectos, a prepararam para essa nova experiência cognitiva, sensorial e principalmente visual.

Algumas premissas desdobram-se das considerações acima. A primeira diz respeito à especificidade narrativa do primeiro cinema, que não pode ser avaliado com base em características que ainda não existem e são parte do cinema posterior, praticado a partir da década de 1910, mas que se consolida no pós-Grande Guerra. Em seus primórdios, ele não possuía ainda um código de linguagem próprio; de curta, às vezes curtíssima duração, os títulos que compõem a filmografia do "primeiro cinema" são também rápidos em seu ritmo narrativo, estranhos e, por vezes, engraçados. A historiadora Flávia Cesarino Costa (2005, p. 17-70) nota nas histórias "uma aparente improvisação nas encenações: há confusão e muito movimento", além de uma "gritante descontinuidade entre planos e cenas na montagem destes filmes". Se em parte estas características se explicam pelas limitações técnicas do período, há outros elementos que nos auxiliam a entendê-las. Tom Gunning (2006, p. 381-388) fala de um "cinema de atrações", que em alguns aspectos se distingue radicalmente daquele que o sucedeu, inclusive do que lhe é imediatamente posterior, o cinema de linguagem clássica surgido 
nos Estados Unidos logo após a Grande Guerra. Tratava-se, inicialmente, de criar o novo público, de envolvê-lo ao máximo na história narrada, que operava em contraste com a apreciação considerada estática do teatro tradicional. Dois procedimentos principalmente eram acionados: incrementar a narrativa com o máximo de ação e movimento (cenas de perseguição são bastante comuns) e fazer "dialogarem" os atores e seus públicos, seja por meio de gestos grandiloquentes e exagerados, ou por rápidas e cúmplices piscadelas da tela em direção ao espectador.

Misturado a uma série de outras atrações com quem disputava a atenção e a excitação do público, o primeiro cinema não pretendia apenas (ou principalmente) contar uma história, mas espantar e maravilhar. Para isso, tomava de empréstimos flagrantes do cotidiano, mostrados em narrativas despretensiosas em suas intenções. São películas que flagram cenas e acontecimentos banais, transformando o espectador em voyeur de hábitos e comportamentos alheios e privados, embaralhando e ressignificando as já tênues fronteiras entre os espaços público e privado. É o caso, entre muitos outros exemplos, de boa parte dos pequenos filmes dos irmãos Lumière, tal como “L'arrouser arrosé" (1896); ou "A romance of the rail" e "What happened in the tunnel", ambos de Edwin Porter (1903); e ainda "How they rob men in Chicago", de Wallace McCutcheon $(1900)^{2}$. Outros, de narrativa mais sofisticada, encenavam dramas provavelmente familiares ao seu público, mas recriando-os em um universo ficcional e espetacular, como são o caso de “The life of an American fireman" (1903) e "The kleptomaniac" (1905), ambos também de Edwin Porter ${ }^{3}$.

O público, heterogêneo, tampouco era inteiramente crédulo nem totalmente ingênuo acerca das representações realistas dos primeiros filmes. De acordo com Tom Gunning, o espectador mantinha com o cinema uma relação até certo ponto ambígua: amparado pelo contato com a parafernália tecnológica de um cotidiano atravessado por representações imagéticas da realidade, o público do cinema não se deixa apanhar inteiramente desprevenido. Por outro lado, "a estreia de imagens fotográficas em

\footnotetext{
${ }^{2}$ Os filmes americanos, respectivamente: "Um romance no trilho"; "O que aconteceu no túnel" e "Como eles roubam homens em Chicago". No caso do pequeno filme dos Lumière, não há uma tradução literal, porque o título propõe um jogo de palavras cuja ideia mais próxima é ade um "regador regado".

${ }^{3}$ Respectivamente: "A vida de um bombeiro americano" e "A cleptomaníaca".
} 
movimento representou um novo lance num antigo jogo de enganar os sentidos e dos misteriosos prazeres que isso evoca", já que o cinema oscilava entre dois polos apenas aparentemente contraditórios: o de ser uma representação realista da realidade e, ao mesmo tempo, apresentar um "sentido de irrealidade, um reino de fantasmas impalpáveis" (GUNNING, 1996, p. 21-44).

E há, enfim, o circuito de exibição dos primeiros filmes, cujo formato e duração permitiam que eles fossem apresentados em meio a outras formas de entretenimento, normalmente como parte de uma programação variada de atrações populares, culturais e tecnológicas. Se os primeiros filmes eram exibidos em circos, teatros, parques de diversões e, principalmente, em vaudevilles - basicamente, em lugares destinados às chamadas diversões populares -, em pouco tempo seu caráter comercial e tecnológico atraiu a atenção de industriais e cientistas, facilitando sua inserção em exposições e círculos de ciência, por exemplo. Uma das razões do fascínio exercido pelo cinema, portanto, foi sua capacidade não apenas de incorporar alguns procedimentos já presentes em gêneros literários consagrados e populares, tais como os romances folhetins, e de expandir suas possibilidades narrativas com o recurso tecnológico e visual. Mas também por seu caráter autônomo "que se encaixava facilmente nas mais diferentes programações", permitindo, entre outras possibilidades, a apresentação de uma carta variada por meio de exibidores itinerantes que, especialmente entre 1895, ano das primeiras exibições públicas do cinematógrafo, até o início do século seguinte, levaram e apresentaram o cinema para cidades distantes dos principais centros urbanos (COSTA, 2005, p. 40-57). Se não se pode falar ainda, nesse contexto, da construção de uma "linguagem cinematográfica", por certo este período assiste a consolidação de um "cinema de atrações" que reafirma seu caráter de novidade tecnológica e diversão popular. É esse cinema que se desloca das cidades europeias e norte americanas, onde surge, para os centros urbanos de sociedades cuja modernidade é ainda incipiente e periférica. 


\section{Cães \& macacos amestrados e viagens à lua}

Em sua edição de janeiro de 1911, a revista "Paraná Moderno" publica, sob o pseudônimo "PATHÉ", um poema que, em seis estrofes de quatro versos cada, presta homenagem e faz propaganda de alguns dos mais afamados espaços de lazer curitibanos nos primeiros anos do século XX:

Todo o pessoal do bom tom, O povo honesto e solerte Desta terra se diverte No COLISEU OU MIGNON.

Porventura há quem despreze a

Canção sonora e bonita

Que canta com infinita

Graça trinula, a DALESIA?

"Il suffit d'un frou-frou" linda

A cançoneta da YETTI

E os quentes quebros da KETTI,

E a REINE AVOR e outra ainda...

O MIGNON é uma delícia, Parece um trecho do céu! Mas quanto encanto e caricia Musical no COLISEU!...

Mignonne, fresca, bonita Não há alma que não seduza Numa canção andalusa, Num SALERO, a CHAVALITA.

Na plástica ninguém vence-a E põe corações de rastro Se gyra no ar como um astro A linda graça da THENSIA. (PATHÉ, 1911)

Se o "COLISEU" e o "MIGNON" são nominalmente mencionados, o bardo anônimo não esquece o "SMART" e o "EDEN", que não aparecem no corpo do poema talvez por alguma restrição de ordem lírica ou métrica. Mas logo abaixo do último verso, o poeta-publicitário faz questão de acrescentar: "O SMART e o EDEN também 
concentram diariamente grandes massas de povo que se diverte. Não há duvida - já entrou nos hábitos de nossa gente com uma necessidade que se impõe, o goso em commum nas casas de diversões". Na mesma edição, algumas páginas adiante, sob o título "Os nossos cartazes", anúncios informavam aos leitores as atrações daquele domingo. No cardápio nem tão variado de entretenimento, sobressaem as seções do “cinematographo", com "soirées diarias", "preços populares” e, exclusivamente no “SMART”, a garantia de “projecções firmes e nítidas” em seu "Salão elegante”.

No começo da segunda década do século XX, ir ao cinema já era uma prática e um entretenimento comuns para os curitibanos, e não apenas entre as camadas social e economicamente mais baixas. Seguindo um percurso bastante similar ao de outras cidades, também na capital paranaense as exibições do cinematógrafo tornaram-se um dos principais atrativos dos parques, clubes e teatros da cidade. Desde a sua primeira exibição, em agosto de 1897, no Teatro Hauer, o cinema aos poucos se descolara da imagem de uma distração exclusivamente popular, e já atraía a atenção de uma população mais abastada, especialmente quando as exibições aconteciam em parques badalados como o Coliseu. Esse interesse crescente, o seu desenvolvimento como espetáculo de massas, como observou Ismail Xavier, se explica em parte pela capacidade dos filmes de irem ao encontro de demandas sociais específicas de sua assistência mais imediata. Tal aproximação se fazia seja por meio de narrativas que reiteravam características já presentes no público, produzindo uma identificação rápida entre plateia e película justamente por sua inscrição em uma "tradição de cultura não erudita, com base em espetáculos populares de entretenimento e diversão, vindo a coexistir e, muitas vezes, substituir as atrações mais antigas como o circo, certas formas de teatro e o show de variedades" (XAVIER, 1978, p. 26).

Com uma população de aproximadamente 50 mil habitantes e de modernização acanhada, Curitiba conhece o cinematógrafo, portanto, de maneira bastante similar a das cidades europeias e de outras capitais brasileiras. Se nas primeiras décadas do século XX a cidade já contava com lugares fixos para a exibição de seus films, poucos anos antes a programação e o acesso ao cinema só eram possíveis por meio de companhias que a visitavam desde os últimos anos do século XIX. Entre os exibidores que aportaram na 
capital a partir de 1897 estão a Empresa Germano Alves, o Cinematógrafo Apollo e o Cinematógrafo Universal do Sr. Kâurt. A programação, e não apenas a fílmica, era bastante diversificada: na mesma noite em que a Empresa Germano Alves exibiu pela primeira vez ao público curitibano a "maravilhosa máquina - o Cinematógrapho Lumière", a Grande Companhia Zoológica exibiu um número de abertura com cães e macacos amestrados (A REPÚBLICA, 8/10/1897). Nos “quadros do cinematógrapho", exibidos na segunda e terceira parte da programação, principalmente filmes provenientes de Portugal, com alguns títulos franceses e um espanhol. Os preços variavam de $1 \$ 000$ e $3 \$ 000$ - as cadeiras gerais e de primeira - a $10 \$ 000$ e $12 \$ 000$ os camarotes de segunda e de primeira classes. Nos anos seguintes a frequência com que as companhias ambulantes voltam à cidade aumenta, bem como o tempo de sua permanência a cada nova passagem. Há uma predominância dos filmes europeus, especialmente franceses, e a preferência é por aqueles de caráter mais documental. A produção nacional só entraria na programação dos exibidores a partir de 1903, inicialmente pela Companhia de Artes de Bioscope Inglez, de José Fellipi, responsável também pelas primeiras filmagens feitas em Curitiba, exibidas como parte da mesma programação em que foram apresentadas as “vistas animadas" do Rio de Janeiro e Guaratinguetá (DIÁRIO DA TARDE, 7/9/1903).

Com a inauguração, em 1905, do Coliseu Curitibano, a cidade ganhou um cinematógrafo fixo, que exibia filmes os mais diversos incluindo, dois anos depois, as primeiras produções locais, todos os finais de semanas. Inicialmente um parque de diversões, depois transformado, a partir de 1910, em uma casa de diversão "estilo music hall", o Coliseu teve no cinema, ao longo de seus mais de dez anos de funcionamento, uma de suas principais atrações, ao ponto de a alta frequência do público obrigar a reformas no espaço destinadas às exibições cinematográficas (BRANDÃO, 1994, p. 6988). Atentos ao potencial comercial representado pelos films, outros empreendedores rapidamente mobilizaram recursos para oferecer salas de projeção a um público cada vez mais ávido pelas novidades: no final da primeira década do século passado, entre teatros, parques e cinemas, Curitiba já contava com sete locais de exibição (STECZ, 1988, p. 67). 
A "febre fílmica" é acompanhada e estimulada pelos jornais, que não apenas divulgam a programação das companhias ambulantes ou dos espaços fixos, mas repercutem, comentam e analisam o fenômeno. Quando a Companhia de Novidades apresentou um "espetáculo apenas para homens" de "vistas picantes", em que era “prohibida a entrada aos menores e às mulheres", o jornal "A República” comentou a sessão, considerando-a justamente "pouco picante", ainda que exibida com "admirável nitidez" (A REPÚBLICA, 24/7/1902). A verdadeira comoção gerada pelo "cinematógrapho fallante", da Companhia Eduardo Hervet, recebeu ampla cobertura. Combinação de filme exibido com o acompanhamento de um gramofone, ele permitia uma sincronização bastante rudimentar, mas excitante para o público, que se deliciava com as músicas que, à medida que as cenas apareciam na tela, acompanhavam a ação. Comentando a novidade, depois de uma primeira sessão especialmente para a imprensa, um jornalista de "A República" afirmou que se tratava da "grande novidade dos últimos tempos esse aparelho que em combinação mathemática, com as modernas machinas fallantes, dá vida as scenas e figuras focalizadas sobre um panno, maravilhando os espectadores com a ilusão de um grupo vivo, a mover-se, a falar, gesticular, representando operetas inteiras e provocando aplausos..." (A REPÚBLICA, 6/7/1905). Um pouco menos entusiasmado, o profissional do concorrente "Diário da Tarde", arvorando-se uma combinação de repórter e crítico de cinema, se refere ao filme de Georges Méliès, "Le voyage dans la lune”, parte da programação, como “àquella xaropada à lua”: à película do diretor francês, a plateia local preferiu as cenas da guerra russo-japonesa, exibidas na mesma sessão (DIÁRIO DA TARDE, 14/7/1905).

Em um período no qual o cinema já havia descoberto e caminhava para consolidar sua capacidade narrativa, além de meramente documental - tendência, aliás, que já se anunciava delicadamente com “L'Arroseur arrosé”, dos irmãos Lumière, pequeno ensaio cômico datado de 1896 - a "xaropada" de Méliès não era um caso isolado. Contemporâneos a "Le voyage dans la lune", de 1902, e de outros títulos do próprio Méliès, são a primeira versão de "Alice in wonderland", dirigido na Inglaterra por Cecil Hepworth e Percy Stow em 1903, e as produções americanas “Execution of Czolgosz with panorama of Auburn Prison", de 1901, e "The great train robbery", de 1903, ambas 
dirigidas por Edwin S. Porter. ${ }^{4}$ Curiosamente, nenhum desses títulos consta na programação dos filmes exibidos em Curitiba nesse período. Depois da crítica do "Diário da Tarde" e da aparente recepção fria do público, em todas as apresentações posteriores, que se estenderam até 5 de agosto, o cinematógrafo do Sr. Hervet lotou o Teatro Guaíra, mas retirou a película de Méliès da programação. Para Luis Fernando Lopes Pereira (2002, p. 99), a explicação é relativamente simples: “o público curitibano ainda preferia as cenas externas. O fascínio naquela pequena cidade, que pretendia ser uma metrópole cosmopolita, era pela multidão nas ruas, pelas cenas de carros, trens, bondes, bicicletas ou as muito aclamadas cenas de guerras, navais ou terrestres". Uma curiosidade tecnológica, uma forma de entretenimento cujo objetivo principal não era contar uma história, mas espantar e maravilhar: esta parece ser a definição e a função do cinema tal como percebido pelos curitibanos do período.

\section{A cidade como atração}

É também nas páginas das revistas que começam a circular já nos primeiros anos do século XX, que encontramos muitas outras manifestações acerca do impacto do cinema em Curitiba e sua contribuição na formação de novas sensibilidades, urbanas e modernas. Seu papel na construção de uma nova "cultura visual" é fundamental. Se por um lado elas desdobram e expandem aquilo que já se pode encontrar nos jornais, por outro o fazem em uma linguagem menos preocupada com o factual, mais reflexiva e rica em metáforas verbais e visuais, além de literariamente mais elaborada. O número de títulos é expressivo: foram cerca de 60 somente nas duas primeiras décadas do século. É verdade que nem todas tiveram vida longa. Mas se houve as de existência efêmera, um pequeno grupo sobreviveu tempo o suficiente para se tornar referência entre o ainda modesto público leitor da cidade. Destas, "O Olho da Rua" parece ser a que melhor exemplifica esta tendência. A revista circulou quinzenalmente entre 1907 e 1911, chegando a manter edições semanais durante um breve período, no começo de 1908. Empreendimento coletivo, como a maioria, o projeto de "O Olha da Rua" era ousado:

\footnotetext{
${ }^{4}$ Respectivamente: "Viagem à lua”; "Alice no país das maravilhas”; "Execução de Czolgosza com panorama da prisão de Auburn" e "O grande roubo do trem".
} 
fartamente ilustrada, com tiragem de 2 mil exemplares iniciais, ela passou a 4 mil a partir do quarto número, mantendo-se mais ou menos estável até o encerramento de suas atividades. Seu conteúdo, bastante diversificado, não era muito diferente dos de outros títulos do período. Abrangendo desde temas políticos e literários, a revista serviu também de trincheira aos anticlericais que combatiam, neste e em outros fronts, a influência da igreja católica em Curitiba. Como o título sugere, a intenção era traduzir em suas páginas um pouco da vida citadina, seus tipos, hábitos, lugares - um projeto, aliás, mais ou menos comum a outras revistas.

Um dos aspectos explorados para falar das mudanças na vida urbana, o divertimento - e como parte dele, o cinematógrafo - é tema de duas crônicas em que os autores o tomam como um dos parâmetros da vida feérica da capital:

A nossa Coritiba vae já se tornando uma cidade bem divertida. Coritiba brinca!, Coritiba folga!

Alem dos três cynematographos permanentes com os seus deliciosos parques, temos por ahi sociedades de tiro, clubs de gymnastica, innumeros clubs recreativos e literarios, sociedades theatraes, um Jockey Club, um Champion Club, etc.

(...)

- O Colyseo e o Eden em varias noites da quinzena abriram ao publico os seus apreciados parques. Os cynematographos funccionaram apresentando excelentes vistas quasi sempre novas.

Dicididamente os dois magníficos logradouros são agora os pontos predilectos da população coritibana (...). (FLAVIO, 1908)

Outro cronista registra que, apesar do "frio intenso" as "casas de diversões, especialmente o Coliseo, Eden e Smart, têm tido grande frequência. É que os cinematographos cada vez mais attrahem, empolgam e deliciam o nosso Zé Povo e a burguezia dinheiruda. Com o magro 500 reis tanto o mais pobre como o mais rico viajam pela Europa, Azia, isto é, em Cairo e em Malta, em Nazareth e no Egypto" (O OLHO DA RUA, 03/7/1909). Em ambos os textos, o cinema é associado a novas experiências sensoriais, mais intensas e frementes. No segundo, particularmente, às sensações descritas acrescenta-se um caráter democrático, de massa, intrínseco ao cinema, que 
delicia o "Zé Povo" e a "burguezia dinheiruda", uns e outros deslocados de país e continente graças às suas possibilidades tecnológicas e imagéticas.

Uma sensibilidade mais aguçada à vida urbana, sua capacidade de exprimir e até certo ponto modelar novas sensações e percepções estéticas, de engajar-se na cultura moderna, testemunhando e significando as mudanças daí advindas, são alguns dos atributos que tornam as revistas atraentes e explicam parte de sua aceitação. “Articuladas à vida cotidiana”, defende Monica Velloso, “elas terão uma capacidade de intervenção bem mais rápida e eficaz, caracterizando-se como 'obra em movimento”'. Suas características a distinguem tanto do livro quanto do jornal: contrapondo-se ao primeiro, que aspira à perenidade, ela não pretende expressar nunca um "pensamento de forma definitiva", articulando-se sempre ao seu tempo e aos acontecimentos que procura apreender e narrar. Sua escrita, no entanto, é dinâmica mas também reflexiva, afastandoa igualmente do jornal: se ambos tomam como objeto e pretexto o cotidiano, suas abordagens são distintas. Ao jornal interessa captar a "atualidade imediata", o tempo acelerado do dia a dia; à revista interessa tomá-lo e torná-lo um "objeto de reflexão", representando-o em seu caráter plural e multifacetado. Ela ocupa, enfim, um lugar intermediário e estratégico entre um e outro. Do jornal, ela mantém a atenção à vida cotidiana. Sem, no entanto, contentar-se em simplesmente noticiar, ela encerra em seus textos, crônicas em sua maioria, uma abordagem que se abre e valoriza o pensamento e a interpretação, no que se aproxima dos livros, ainda que seu caráter efêmero e periódico torne sua escrita provisória e inacabada (VELLOSO, 2010, p. 43-44). A modernidade encontra, nas revistas, um veículo e uma escrita coerentes com sua frágil e paradoxal solidez.

$\mathrm{Na}$ capital paranaense, parte dos textos publicados nas revistas procurou comunicar os meios conflituosos, precários e não raro fragmentados pelos quais foram sentidas as muitas mudanças vividas ao longo deste período. E, com frequência, tal comunicação se faz a partir de uma escrita que mimetiza as narrativas fílmicas, selecionando, enquadrando e montando fragmentos de um olhar que acabam por constituir cenas de uma cidade em permanente movimento. Não por acaso, nas suas 
páginas a rua ocupa um lugar privilegiado. Devidamente enquadrada em textos e imagens, por ela circulam coisas e corpos, mas são os corpos que importam mais. No texto que inaugura a coluna sugestivamente intitulada "Na esquina", Helio (pseudônimo de Euclides Bandeira) justifica e explica aos leitores sua escolha por um ponto de vista privilegiado, de onde se vê "a rua toda":

Aqui é o meu ponto favorito; é como se estivesse na platéa de um grande theatro, attento para o palco onde se desenrolassem, trágicas e terríveis as scenas palpitantes de um drama real. A rua é um tablado e quem ficar para ahi, acantoado ao desvão de um palacete há de assistir lances multiformes, imprevistos, terrificantes, buffos; há de apanhar no ar trechos de ineffaveisdialogos de amor, imprecações brutaes de carrejões, lamurias de mendigos, risadas e blasphemias; ha de auscultar emfim, esse organismo que estua, vibra, e é alegre e triste, faustoso e miserável, cheio de sol e cheio de lama. (HELIO, 1907)

E se Helio prefere ainda a metáfora do "teatro" para, como espectador, olhar da plateia a paisagem urbana, em outra revista é o cinema que, desde o título, serve de referência. Em seu editorial de estreia, os fundadores assim definem a nova publicação:

Cinema é uma cousa pouco definida pelos diccionarios, mas muito conhecida do publico. É ou deve ser a applicação dos movimentos.

Por isso no Cinema, que ora surge em publico, nós vamos aproveitar todas essas figuras, as mais salientes e mais distinctas, e pôl-as em foco, coordenando os movimentos para uma scena cômica, dramática, trágica ou patética.

(...)

Ora, quem já apresentou uma plataforma assim tão nítida, ao alcance de todas as intelligencias, como ora fazemos? Nem a mensagem do Monsenhor, nem o manifesto Menezes Doria foram assim tão concisos, ou sem os ditos?...

(...)

Aqui os figurantes hão de apparecer a caracter original e legitimo.

Uma secção gentil, ao bello sexo, outra hilariente a infância feliz.

O que for bom, emfim, e o que for útil, para compensar os males da vida, por essas paginas adiante hão de vir, á penna e a lápis. (CINEMA, 1909) 
Apesar do título, a "Cinema" não era uma revista dedicada ao cinema, mas a “temas banais do cotidiano político e social da cidade”. Sua circulação foi breve - oito números entre janeiro e maio de 1909; com pouco mais de 20 páginas por edição, era vendida a \$300 o exemplar. Sobre o nome, me apoio na descrição que fazem dela os responsáveis pelo projeto "Revistas Curitibanas": "O título do periódico é metafórico, pois toma a idéia do cinema no sentido das "vistas", ou seja, registros de flagrantes dos movimentos diários na sociedade, como aquelas amenidades que o público do cinematógrafo via nos films. Na capa do primeiro número da revista essa idéia fica explícita através da imagem assinada por Célio: vê-se o interior de um auditório, de frente para a platéia lotada, e a posição do leitor da revista parece ser a do palco (ou da tela na qual se exibirão os films). A legenda - "Está na hora, está na horaaa" - indica a iminência do início do espetáculo (assim que virarmos a página, a revista mostrará o espetáculo da sociedade na qual o próprio leitor poderá se ver)". ${ }^{5}$

Nas edições seguintes, o cinema aparece em uma série de menções mais ou menos diretas, da diagramação da revista, disposta de tal forma que de suas páginas saltam "quadros" do cotidiano curitibano, aos anúncios, abundantes. É o caso, também, da revista "A Rolha". De duração igualmente efêmera - 14 edições ao longo do ano de 1908 - a revista, de cunho mais satírico, publicou nos cinco primeiros números anúncios de página inteira chamando os curitibanos às sessões do "Coliseu”, onde funcionará “o único cinematógrapho que tem aparecido no Paraná sem trepidação" (A ROLHA, 1908). A promessa se repete em outra edição, mas desta vez com a garantia de que o parque oferece "Sempre vistas novas" e "Sensacionaes novidades (...) de magnífico effeito e sempre desconhecidas vindas diretamente da França e da Allemanha" (A ROLHA, 1908). Ilustrados por artistas locais, os reclames produziam um efeito visual que repercutia a relação do público com o parque e o cinema: em um deles, por exemplo, o da edição número 1, o cinematógrafo é literalmente "anunciado" por um personagem que leva nas mãos um cartaz ao mesmo tempo em que, o desenho assim o sugere, grita as informações ao público - no caso, os leitores da revista. Essa espécie de metalinguagem

\footnotetext{
${ }^{5}$ Projeto Revistas Curitibanas: 1900-1920. Disponível em:

http://www.revistascuritibanas.ufpr.br/ordemalfabetica.php\#. Acesso em 10/11/2015.
} 
amplamente utilizada em “A Rolha”, ganha contornos mais interessantes em seu último número: nele, sob o título "O nosso cinematógrapho", desenhado em letras grandes e em estilo art noveau, o anúncio literalmente conta uma história em sete quadros. Diante de si o leitor, transformado em espectador, não apenas lê um anúncio, mas vê um pequeno filme (A ROLHA, 1908).

Mas é na já mencionada "Paraná Moderno" que uma breve nota de lamento escapa em meio às narrativas em que predomina um tom quase sempre ufanista. Logo abaixo do poema em que menciona o Smart e o Coliseu, reproduzido anteriormente, o autor se posiciona de maneira um pouco mais cética sobre os eventuais riscos da excessiva exposição especialmente ao cinema. Em nota breve e transbordada de um indisfarçável saudosismo, lamenta que a afluência a espaços como o "Coliseu" tenha implicado o declínio do "theatro da grande arte - do drama e da ópera! Nada mais resiste á contagiosa influencia das FILMS e das cançonetas. Quer-se a arte solerte, bregeira e rápida. A época é dos instantâneos, imagem da vida fugidia. O symbolo do tempo é o relâmpago" (PATHÉ, 1911).

O temor do empobrecimento estético como resultado da excessiva exposição aos “instantâneos", presente também em outros textos e publicações revelam, segundo Rosane Kaminski (2012, p. 229-272), os diferentes níveis de percepção e de produção cultural dos curitibanos da belle époque. Segundo ela, quando PATHÉ e os editores da “Paraná Moderno" se referem à grande arte, "certamente aí também se observa a influência européia, mas essa referência é clara às produções de uma arte de elite, destinada às minorias, anterior à popularização de um consumo cultural”. A “democratização do acesso à cultura” argumenta, "incorria no rebaixamento do nível de informação e, conseqüentemente, de refinamento estético: os padrões perenes de uma cultura nobre eram substituídos pela imagem fugidia cuja metáfora é o 'relâmpago', representando aquilo que é passageiro e de rápida apreensão".

A preocupação não é exclusiva à província. Distante milhares de quilômetros, Kracauer criticava em texto de 1926 - posterior, portanto ao do jornalista curitibano -, a 
propensão dos grandes espetáculos cinematográficos berlinenses a reforçar em seu público, de idades, gêneros e classes heterogêneas, "a excitação dos sentidos [que] se sucede sem interrupção, de modo que não haja espaço para a mínima reflexão" (KRACAUER, 2009, p. 346). O cinema funcionaria como uma espécie de evasão a uma existência cotidiana desprovida de experiências significativas, uma compensação ao tédio - o que explica, ainda segundo Kracauer, sua capacidade de atrair, sem distinção, burocratas de repartições e escritórios públicos e privados e operários de fábrica; homens e mulheres; velhos e jovens, uns e outros carentes da excitação oferecida pela ilusão de realidade das imagens fílmicas.

A aproximar a crítica do historiador alemão e o receio do misterioso PATHÉ, apesar da distância oceânica a separá-los, a percepção de que as imagens cinematográficas, com sua mecanicidade, seu valor de mercado a substituir o valor de culto, seu ritmo intenso, constante e veloz; enfim, que as imagens cinematográficas traziam subjacente o risco do entorpecimento da sensibilidade, da suspensão da apreciação estética e do juízo crítico. Seu caráter alienante aparecia ainda na já observada heterogeneidade de seu público, diverso em suas características e expressivo na quantidade. E para isso foi fundamental a “vocação" industrial e comercial do cinema: a produção fílmica em série; cada filme sendo reproduzido mecanicamente em inúmeras cópias; cada cópia sendo exibida em salas amplas o bastante para acomodarem um número sempre maior de espectadores; cada espectador pagando um preço irrisório para ver desfilar, diante de si, a vida transformada em espetáculo; o espetáculo exibindo um simulacro que ao ampliar as possibilidades do visível, torna a "realidade cinematográfica" mais intensa e excitante que seu referente, a "realidade vivida".

Por outro lado, há na relação do público curitibano com o cinema singularidades que é preciso ressaltar. A proliferação das imagens é um dos elementos chaves para se entender a experiência da modernidade. Se esta pressupõe a mobilidade e a mudança constantes, a ausência de referências estáveis, a imagem, articulada aos novos recursos técnicos disponíveis, cumpre um papel essencial: ela pretende devolver à cidade a ideia de uma fixidez e solidez possíveis como antídotos ao incômodo gerado pela instabilidade. Trata-se, em linhas gerais, da possibilidade de "eternizar" o instante único. Esse desejo de 
perenidade, ainda que traduza uma necessidade psíquica inconsciente, cria e alimenta-se de uma ilusão: fixar no tempo aquela experiência que não pode ser plenamente vivida, ou só o pode frágil e transitoriamente. Um dos desdobramentos deste "regime de visualidade" é a própria espetacularização da cidade, a metrópole tornando-se, nas palavras de T. J. Clark, "um campo livre de signos e objetos expostos, uma massa negociável de imagens" (CLARK, 2004, p. 91).

Mas em Curitiba esta espetacularização, se não é tardia - afinal, ela acompanha praticamente "em tempo real" o avanço do cinema nas grandes metrópoles -, é periférica, naquele sentido que atribui ao termo Beatriz Sarlo: a tentativa de articular as linguagens modernas produzidas no "Velho Mundo" às tradições e costumes locais, fazendo emergir novas "identidades" - estéticas, étnicas, políticas, etc... - capazes de aproximar, se não mesmo harmonizar, passado e futuro, tendo o presente como ponto de encontro e inflexão (SARLO, 2010, p. 25-26). Na capital paranaense, este novo regime de visualidade, essa espetacularização da cidade, se constrói sobre as bases de uma modernização precária, sob diferentes aspectos: pouco populosa; um núcleo urbano restrito praticamente à região central, uma ilha citadina cercada de amplas e distantes zonas rurais; uma vida intelectual que, embora dinâmica, era vivida em relativo isolamento... Tudo isso contribuiu para que, inclusive, os gostos e percepções estéticas dos curitibanos, mesmo entre aqueles que se consideravam modernos, tivessem algo de naif, o que ajuda a compreender, por exemplo, a reação adversa a filmes como os de Méliès e a preferência por documentários, "vistas" de cenas cotidianas, de desfiles ou de batalhas, da "realidade", enfim.

Há pelo menos duas razões para isso, a meu ver, exemplarmente sintetizadas em crônica publicada na revista "O Paraná". Assinada com o pseudônimo "Nautilus", o texto abre constatando a novidade dos "filmes cinematográphicos que deslisam nas telas poerentes da cidade" para, em seguida, equiparar a cidade a um "grande cinematographo que tem por espectadores o povo e por empresário a natureza. Os programmas exibidos succedem-se com a velocidade do relâmpagos e os films são sempre novos". A crônica prossegue descrevendo o que Nautilus considera o filme mais interessante da temporada, o "Dia de Finados": 
Durante esta quinzena a fita que mais impressão causou, foi a de Finados. Para os que se dedicam aos estudos da psychologia, esta fita é uma encyclopedia, ou antes, um grante theatro, onde se representa juntamente a tragédia, o drama, os vaudevilles, a revistas e as comedias.

2 de novembro, desde as 7 horas da manhã, Coritiba regorgitava de povo que se dirigia, formigando pelas ruas, em romaria ao campo santo.

Deixei o meu leito, ou por outra, o meu tumulo provisório, para perderme no tovelinho incessante da cidade.

Fui ao cemitério (NAUTILUS, 1910).

Os parágrafos seguintes descrevem a atmosfera de Finados, um dia com um “mixto de alegria e tristeza", e se detém sobre os contrastes que testemunha nas tumbas da "nossa necrepole": a suntuosidade de alguns mausoléus que pareciam querer "sufocar a modesta simplicidade dos pequenos túmulos, dos túmulos pobres", uma "pompa inútil, que parecia querer media a nobreza do mérito pelo fulgor das aparências", diz, e encerra com um tom entre cético e indignado: “E eu então possui-me de um scepticismo intranseigente que me representou na imaginação o campo santo como um logar de exhibições, um sport de mundanidades e o 2 de novembro como um grande carnaval" (NAUTILUS, 1910).

A crônica é duplamente reveladora. Ela mostra, inicialmente e a um nível mais amplo, a afinidade com uma prática que se tornou comum nas cidades europeias principalmente a partir da segunda metade do XIX. O culto aos mortos e a visita frequenta aos cemitérios, se inicialmente inspirados no positivismo e em seu apego conservador ao passado e à tradição (MARTIN-FUGIER, 1991, pp. 224-227), são rapidamente ressignificados. Já no final do século, em parte estimuladas pelas notícias publicadas na imprensa popular, especialmente em Paris, pequenas multidões fizeram das idas ao necrotério da capital francesa um passeio frequente. Transformado em um espetáculo visual e de entretenimento comparável ao teatro - uma forma de “voyeurismo público - flânerie a serviço do estado" -, o necrotério "satisfazia e reforçava o desejo de olhar que tanto permeou a cultura parisiense" (SCHWARTZ, 2004, p. 340). 
Mas a crônica de "Nautilus" revela, igualmente, que o fascínio do público curitibano pelo cinema está ligado principalmente às suas possibilidades técnicas. Se "ela é [a técnica] em, parte, o próprio espetáculo", e se o cinema cumpre a função de, sobretudo, reafirmar sua presença cotidiana como um componente intrínseco fundamental à vida moderna, filmes com alguma confecção narrativa mais elaborada - ou simplesmente com uma narrativa - tinham poucas chances de serem vistos como algo mais que uma "xaropada". E se a crônica prioriza, do cinema, sua dimensão técnica, nela a cidade aparece como um filme "onde todos os acontecimentos se projetam e se desenrolam para o espectador atento que pode deleitar-se com os mesmos. É o lugar da ação", segundo Berberi (1998, p. 72). Mas tal representação não parece produzir senão uma certa melancolia nesse espectador privilegiado. Se "a fita" a que ele assiste "é uma encyclopedia, ou antes, um grande theatro, onde se representa juntamente a tragédia, o drama, os vaudevilles, as revistas e as comedias", fica igualmente a sensação de estranhamento, ou mesmo um alheamento em relação à cidade: o autor a assistisse mas, justamente por isso, e ainda que se trate de um observador especial, age como se não pudesse mais tomar parte dela.

Esse estranhamento revela, de acordo com Sennett (1992, p. 15-20), uma cisão entre as experiências subjetiva, interior, e a material, exterior, característica das cidades modernas. Nelas, os espaços comuns são consagrados exclusivamente ao consumo e ao espetáculo, poucas condições havendo para o exercício de subjetividades partilhadas e para a constituição de laços mais intensos com a própria cidade. Diferente da experiência, por exemplo, dos antigos gregos, nós não podemos "olhar a cidade" mas, tão somente, assisti-la - como um filme em longa metragem. A contradição gerada pela consciência, mesmo que inconsciente, desta condição, ilumina a relação ela própria ambígua dos curitibanos com o cinema. A historiadora Elizabete Berberi percebeu até certo ponto isso ao analisar a mesma crônica. Segundo ela, "ele [o narrador] pode instalar-se 'confortavelmente' em seu posto, como se estivesse mesmo na platéia de um cinematógrafo, e relatar o que assiste” (BERBERI, 1998, p. 72). Mas há, nesse conforto, uma constatação algo melancólica que escapa à sua leitura: ele implica um afastamento da cidade, o sentimento incômodo de não mais pertencer a ela. A condição de 
espectador, afinal, não é equivalente a do cidadão, porque a ação se desenvolve fora dele, e embora ela o afete, ele nada pode fazer para afetá-la. A distração e a evasão cinematográficas, criticadas em artigos do período, ganham então um outro sentido, e a experiência do cinema, que é também a da modernidade, significa tanto um reencantamento imagético e imaginário da cidade, como a alienação em relação a ela. Ser um personagem em uma trama que se desenvolve diante de seus olhos, fazer parte dela não apenas como mero espectador, parece ser a aspiração de alguns cronistas curitibanos, que advogam um olhar capaz de resgatar a cidade das telas, ou de se colocar dentro delas.

\section{Fontes}

A República, Curitiba, 8/10/1897.

A República, Curitiba, 24/7/1902.

A República, Curitiba, 6/7/1905.

A ROLHA. Curitiba, Anno 1, n. 1, 1908.

A ROLHA. Curitiba, Anno 1, n. 41908.

A ROLHA. Curitiba, Anno 1, n. 141908.

CINEMA. Cinema. Curitiba, Anno1, n. 1, 1909.

Diário da Tarde, Curitiba, 3/9/1903.

Diário da Tarde, Curitiba, 7/9/1903.

Diário da Tarde, Curitiba, 14/7/1905.

DIVERSÕES. O Olho da Rua. Curitiba, 03/7/1909. Anno III, n. 55.

FLAVIO. Diversões. O Olho da Rua. Curitiba, 15/4/1908. Anno II, n. 26. 
HELIO. Na esquina. O Olho da Rua. Curitiba, 13/4/1907. Anno I, n. 1.

NAUTILUS. Impressões. O Paraná. Curitiba, 15/11/1910. Anno V, n. 41.

PATHÉ. Onde a gente se diverte. Paraná Moderno, Curitiba, janeiro de 1911. Anno Segundo, n. 7.

\section{Referências}

BAUDELAIRE, Charles. O pintor da vida moderna. In.: BAUDELAIRE, Charles. A invenção da modernidade (sobre arte, literatura e música). Lisboa: Relógio D’Água, 2006, p. 287.

BENJAMIN, Walter. A obra de arte na era de sua reprodutibilidade técnica. In.: BENJAMIN, Walter. Magia e técnica, arte e política. (Obras escolhidas, v.1). São Paulo: Brasiliense, 1993.

BERBERI, Elizabete. Impressões: a modernidade através das crônicas no início do século em Curitiba. Curitiba: Aos Quatro Ventos, 1998.

BRANDÃO, Angela. A fábrica de ilusão: o espetáculo das máquinas num parque de diversões e a modernização de Curitiba (1905-1913). Curitiba: Prefeitura Municipal de Curitiba, 1994.

CLARK, T. J. A pintura da vida moderna: Paris na arte de Manet e de seus seguidores. São Paulo: Companhia das Letras, 2004.

COSTA, Flávia Cesarino. O primeiro cinema: espetáculo, narração, domesticação. Rio de Janeiro: Azougue Editorial, 2005.

CRARY, Jonathan. Suspensões da percepção: atenção, espetáculo e cultura moderna. São Paulo: Cosac Naify, 2013.

CRARY, Jonathan. Techniques of the observer: on vision and modernity in the nineteenth century. Cambridge: MIT Press, 1992.

GUNNING, Tom. The cinema of attraction[s]: early film, its spectator and the Avant-Garde. In.: STRAUVEN, Wanda (Edit.). The cinema of attractions reloaded. Amsterdam: Amsterdam University Press, 2006. 
GUNNING, Tom. Cinema e história. In.: XAVIER, Ismail. (Org.). O cinema no século. São Paulo: Imago, 1996.

KAMINSKI, Rosane. Gosto brejeiro: as revistas ilustradas e a formação de juízos estéticos em Curitiba (1900-1920). In: BREPOHL, Marion; CAPRARO, André Mendes; GARRAFFONI, Renata Senna (Orgs.). Sentimentos na história: linguagens, práticas, emoções. Curitiba: Editora UFPR, 2012.

KRACAUER, Siegfried. O ornamento da massa. São Paulo: Cosac Naify, 2009.

MARTIN-FUGIER, Anne. Os ritos da vida privada burguesa. In: PERROT, Michelle (Org.). História da vida privada: da Revolução Francesa à Primeira Guerra (v. 4). São Paulo: Companhia das Letras, 1991.

PEREIRA, Luis Fernando Lopes. $O$ espetáculo dos maquinismos modernos: Curitiba na virada do século XIX ao XX. 2002, 218 f. Tese (doutorado em História) - Universidade de São Paulo, Doutorado em História. São Paulo, 2002.

SARLO, Beatriz. Modernidade periférica: Buenos Aires, 1920 e 1930. São Paulo: Cosac Naify, 2010.

SCHWARTZ, Vanessa. O espectador cinematográfico antes do aparato do cinema: o gusto do público pela realidade na Paris fim-de-século. In: CHARNEY, Leo; SCHWARTZ, Vanessa (Orgs.). O cinema e a invenção da vida moderna. São Paulo: Cosac \& Naify, 2004.

SCHWARTZ, Vanessa. Spectacular realities: early mass culture in fin-de-siècle Paris. Los Angeles: University of California Press, 1998.

SENNETT, Richard. La ville à vue d'oeil: urbanisme et société. Paris: Plon, 1992.

SINGER, Ben. Modernidade, hiperestímulo e o início do sensacionalismo popular. In: CHARNEY, Leo; SCHWARTZ, Vanessa (Orgs.). 0 cinema e a invenção da vida moderna. São Paulo: Cosac \& Naify, 2004.

STECZ, Solange. Cinema paranaense - 1900-1930. 191 f. Dissertação (mestrado em História) - Universidade Federal do Paraná. Mestrado em História. Curitiba, 1988.

VELLOSO, Monica Pimenta. As distintas retóricas do moderno. In: OLIVEIRA, Cláudia; VELLOSO, Monica; LINS, Vera. O moderno em revistas: representações do Rio de Janeiro de 1890 a 1930. Rio de Janeiro: Garamond, 2010.

XAVIER, Ismail. Sétima arte: um culto moderno. São Paulo: Perspectiva, 1978. 
Recebido em: 19/11/2015 Aprovado em: 18/05/2016

Universidade do Estado de Santa Catarina - UDESC Centro de Ciências Humanas e da Educação - FAED

Revista PerCursos

Volume 17 - Número 33 - Ano 2016 revistapercursos@gmail.com 